\title{
Stress-induced inhibition of LH pulses in female rats: role of GABA in arcuate nucleus
}

\author{
XiaoFeng Li, ${ }^{1,2}$, Bei Shao', ChengCheng Lin ${ }^{3}$, Kevin T O’Byrne ${ }^{2}$ and YuanShao Lin ${ }^{1,2}$ \\ ${ }^{1}$ First Department of Neurology, First Affiliated Hospital of Wenzhou Medical University, Wenzhou 325000, China \\ ${ }^{2}$ Division of Women's Health, School of Medicine, King's College London, Guy's Campus, London, UK \\ ${ }^{3}$ Department of Surgery Laboratory, First Affiliated Hospital of Wenzhou Medical University, \\ Wenzhou 325000, China
}

Correspondence

should be addressed

to $Y$ Lin

Email

linyuanshao@hotmail.com

\begin{abstract}
Stress exerts profound inhibitory effects on reproductive function by suppression of the pulsatile release of $\mathrm{GnRH}$ and therefore $\mathrm{LH}$. Besides the corticotrophin-releasing factor (CRF), this effect also might be mediated via GABAergic signaling within the arcuate nucleus (ARC) since its inhibitory effects on LH pulses and increased activity during stress. In the present study, we investigated the role of endogenous GABAergic signaling within the ARC in stressinduced suppression of $\mathrm{LH}$ pulses. Ovariectomised oestradiol-replaced rats were implanted with bilateral and unilateral cannulae targeting toward the ARC and lateral cerebral ventricle respectively. Blood samples $(25 \mu \mathrm{l})$ were taken via chronically implanted cardiac catheters every $5 \mathrm{~min}$ for $6 \mathrm{~h}$ for measurement of LH pulses. Intra-ARC infusion of GABA receptor antagonist, bicuculline $(0.2 \mathrm{pmol}$ in $200 \mathrm{nl}$ artificial cerebrospinal fluid (aCSF) each side, three times at 20-min intervals) markedly attenuated the inhibitory effect of lipopolysaccharide (LPS; $25 \mu \mathrm{g} / \mathrm{kg}$ i.v.) but not restraint (1 h) stress on pulsatile LH secretion. In contrast, restraint but not LPS stress-induced suppression of LH pulse frequency was reversed by intra-ARC administration of $G_{A B A} R$ antagonist, CGP-35348 (1.5 nmol in $200 \mathrm{nl}$ aCSF each side, three times at 20-min intervals). Moreover, intra-ARC application of either bicuculline or CGP-35348 attenuated the inhibitory effect of CRF ( $1 \mathrm{nmol}$ in $4 \mu$ l aCSF, i.c.v.) on the LH pulses. These data indicate a pivotal and differential role of endogenous $G_{B B} A_{A}$ and $G A B A_{B}$ signaling mechanisms in the $A R C$ with respect to mediating immunological and psychological stress-induced suppression of the $\mathrm{GnRH}$ pulse generator respectively.
\end{abstract}

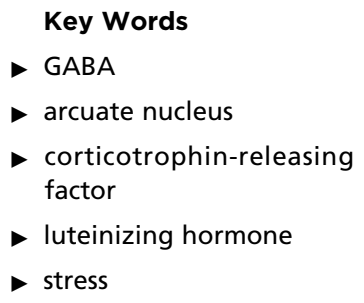

\section{Introduction}

Gamma-aminobutyric acid (GABA), the principal inhibitory neurotransmitter in the CNS, has been implicated in the modulation of the reproductive system. Its physiological function is majorly mediated via two major receptor subtypes: ionotrophic $\mathrm{GABA}_{\mathrm{A}}$ receptor $\left(\mathrm{GABA}_{\mathrm{A}} \mathrm{R}\right)$ and metabotrophic $\mathrm{GABA}_{\mathrm{B}}$ receptor $\left(\mathrm{GABA}_{\mathrm{B}} \mathrm{R}\right)$. Although investigations on the role of $\mathrm{GABA}$ in the gonadotrophin-releasing hormone (GnRH) pulse generator have focused on the effect of manipulating GABA levels in the medial preoptic area (mPOA) (Li et al. 2011, Lin et al. 2012), which is the major GnRH neurons site in the rat, a caveat to consider is the overwhelming evidence that the neural construct comprising the $\mathrm{GnRH}$ pulse generator resides in the arcuate nucleus (ARC) of the mediobasal

Published by Bioscientifica Ltd 
hypothalamus (MBH) in rat and other species such as primates (Plant et al. 1978, Ohkura et al. 1991). Indeed, GABA has been demonstrated to alter the release of GnRH from the ARC-median eminence fragments incubated in vitro (Masotto et al. 1989), and administration of GABA directly into the ARC significantly inhibit pulsatile luteinizing hormone (LH) secretion in rats (Nishihara \& Kimura 1987). Furthermore, both GABA receptor subtypes in the ARC appear to be involved in the modulation of pulsatile $\mathrm{LH}$ secretion. The suppression of $\mathrm{LH}$ pulse frequency in response to intra-ARC of $\mathrm{GABA}_{\mathrm{A}} \mathrm{R}$ agonist or antagonist in castrated rams has led to the suggestion that normal operation of the GnRH pulse generator may require tonic GABAergic input and deviation from this results in dysfunction of the hypothalamic oscillator (Ferreira et al. 1996, 1998). However, controversially, Kimura et al. (1993) reported that continuous systemic injection of $\mathrm{GABA}_{\mathrm{A}} \mathrm{R}$ antagonist, readily elicits seizures that are associated with MUA volley frequency, but in the absence of behavioral seizures, GnRH pulse generator frequency is not affected in the rat. As regards to the $G_{A B A} R$, although infusion of $G_{A B A} R$ agonist or antagonist into the ARC-median eminence region is shown to have no effect on LH pulse frequency in castrated sheep or female monkeys (Ferreira et al. 1996, Mitsushima et al. 2003), $\mathrm{GABA}_{\mathrm{B}} \mathrm{R}$ activation in the $\mathrm{ARC} / \mathrm{MBH}$ is demonstrated to increase LH pulse amplitude (Ferreira et al. 1996) and reverse the negative feedback effect of oestradiol $\left(\mathrm{E}_{2}\right)$ or testosterone on LH release (Jackson \& Kuehl 2002) in sheep.

Stress exerts profound inhibitory effects on reproductive function by suppressing the pulsatile release of GnRH and therefore $\mathrm{LH}$, with different stressors acting through distinct neural pathways and involving various neurotransmitter systems (Li et al. 2010). Recently, we demonstrated that endogenous GABA signaling within the mPOA is involved in the stress-induced suppression of LH pulses (Lin et al. 2012). Nevertheless, neurons in the ARC receive dense direct GABAergic inputs (Decavel \& van den Pol 1990), contain both GABA receptor subtypes (Anderson \& Mitchell 1986) and display altered excitability in response to GABA receptor activation (Wagner et al. 1999, Muroya et al. 2005). Moreover, levels of GABA and/or its synthesizing enzyme glutamic acid decarboxylase 67 $\left(\mathrm{GAD}_{67}\right)$ are increased in the ARC in response to various stressors, including immunological challenge such as lipopolysaccharide (LPS) and interleukin-1 (Akema et al. 2005, Sirivelu et al. 2009), as well as psychogenic restraint stress (Bowers et al. 1998). More importantly, we demonstrated that activation of GABAergic neurons in ARC may contribute to restraint stress-induced suppression of pulsatile LH secretion (Y S Lin, X F Li and K T O'Byrne, unpublished observation). In addition, bacterial endotoxin-induced suppression of GnRH release from the incubated hypothalamic $\mathrm{POA} / \mathrm{MBH}$ fragments in vitro is mediated by both GABA receptor subtypes (Feleder et al. 1996). Therefore, there is no reason to exclude the possibility that GABAergic signaling within the ARC might contribute to the modulation of pulsatile $\mathrm{LH}$ secretion under stressful conditions.

Corticotrophin-releasing factor (CRF) has been demonstrated to play a pivotal role in stress-induced suppression of pulsatile LH secretion (Rivier \& Vale 1985, Li et al. 2010). However, the failure to find any back-filled CRF cells from major CRF neuronal populations to GnRH perikarya using tract-tracing in rats (Hahn et al. 2003), suggests the CRF-mediated suppression of GnRH pulse generator activity may primarily involve indirect regulatory mechanisms. CRF has been shown to stimulate the release of GABA in a dose-related manner in some stressrelated sites (Kash et al. 1999, Roberto et al. 2010). Moreover, the suppression of pulsatile LH secretion in response to i.c.v. administration of CRF is associated with activation of GABAergic neurons in the ARC. Nevertheless, it remains to be established whether GABA signaling within the ARC participates in the suppression of CRF on LH pulses.

The present study was designed to investigate the role of ARC GABAergic signaling in stress- and CRF-induced suppression of GnRH pulse generator by determining whether intra-ARC administration of selective $\mathrm{GABA}_{\mathrm{A}} \mathrm{R}$ or $\mathrm{GABA}_{\mathrm{B}} \mathrm{R}$ antagonist blocks the suppression pulsatile $\mathrm{LH}$ secretion in rats. We further investigated whether $G A B A_{A} R$ or $G_{A B A_{B} R}$ antagonists have a differential role in suppression of pulsatile LH secretion in response to different types of stressful challenge, such as restraint and LPS.

\section{Material and methods}

\section{Animals and surgical procedures}

Adult female Sprague-Dawley rats (weighting 220-250 g) obtained from Charles River (Manston, UK) were housed under controlled conditions $(12 \mathrm{~h}$ light: $12 \mathrm{~h}$ darkness cycle; lights on at $0700 \mathrm{~h}$; temperature at $22 \pm 2{ }^{\circ} \mathrm{C}$ ) and provided with food and water ad libitum. All animal procedures were performed in accordance with the United Kingdom Home Office Regulations. All surgical procedures were carried out under ketamine anaesthesia $(100 \mathrm{mg} / \mathrm{kg}$

Published by Bioscientifica Ltd 
i.p.; Pharmacia and Upjohn Ltd, Crawley, UK) and xylazine $(10 \mathrm{mg} / \mathrm{kg}$ i.p.; Bayer). Rats were bilaterally ovariectomised and implanted with a Silastic capsule (Sanitech, Havant, UK), filled to a length of $25 \mathrm{~mm}$ with $\mathrm{E}_{2}$ (Sigma-Aldrich Ltd) dissolved at a concentration of $20 \mu \mathrm{g} / \mathrm{ml}$ arachis oil (Sigma-Aldrich). The $\mathrm{E}_{2}$-containing capsules produced circulating concentrations of $\mathrm{E}_{2}$ within the range observed during the diestrous phase of the estrous cycle $(\sim 38.8 \pm 1.2 \mathrm{pg} / \mathrm{ml})$ as previously described (Cagampang et al. 1991).

To investigate the effect of intra-ARC application of GABA receptor antagonists on stress- and CFR-induced suppression of pulsatile LH secretion, rats were implanted with bilateral guide cannula (22 gauge; Plastics One, Roanoke, VA, USA) directed towards the ARC, following the coordinates: $0.4 \mathrm{~mm}$ lateral, $3.3 \mathrm{~mm}$ posterior to bregma and $10.2 \mathrm{~mm}$ below the surface of the dura (Paxinos \& Watson 1986). For experiments involving CRF administration, separate groups of rats were fitted with unilateral i.c.v. guide cannula (22 gauge; Plastics One) positioned towards the left lateral cerebral ventricle, following the coordinates: $4.4 \mathrm{~mm}$ lateral, $3.7 \mathrm{~mm}$ posterior to bregma and $5.9 \mathrm{~mm}$ below the surface of the dura (Paxinos \& Watson 1986), in addition to the intra-ARC cannulae. The guide cannulae were secured using dental cement (Dental Filling Ltd, Swindon, UK) and fitted with dummy cannulae (Plastics One) to maintain patency. All brain cannulae were implanted at the same time of ovariectomy. After a 10-day recovery period, the rats were fitted with two indwelling cardiac catheters via the jugular veins, as described previously (Lin et al. 2011). Experimentation commenced 3 days later. Cannula placement was verified by histological inspection at the end of experiment, and animals with cannulae tips located outside the ARC were excluded from analysis.

\section{Intra-ARC infusion of bicuculline or CGR-35348 on stress- or CRF-induced suppression of the GnRH pulse generator}

To test whether the stress-induced suppression of LH pulses was mediated by endogenous GABAergic signaling in the ARC, we examined the effect of intra-ARC administration of selective $\mathrm{GABA}_{\mathrm{A}} \mathrm{R}$ (bicuculline; Sigma-Aldrich) or $\mathrm{GABA}_{\mathrm{B}} \mathrm{R}$ (CGP-35348; Sigma-Aldrich) antagonist on the restraint and LPS stress-induced suppression of pulsatile LH secretion. With respect to the evidence from other studies (Kimura et al. 1993, Hiruma et al. 1994), we established a regimen of bicuculline in preliminary studies (three injections of $0.2 \mathrm{pmol}$ bicuculline/ $200 \mathrm{nl}$ artificial cerebrospinal fluid (aCSF) per injection bilaterally into the
ARC) that did not cause seizures. Similarly, the selection of the dosage for CGP-35348 was also based on the evidence from other studies and our preliminary studies (Scott \& Clarke 1993a, Sirivelu et al. 2009). On the morning of experimentation, a bilateral internal injection cannula (Plastics One) with extension tubing, preloaded with bicuculline, CGP-35348 or aCSF as vehicle control was inserted into the guide cannula, extending $1.0 \mathrm{~mm}$ beyond its tip to reach the ARC. The distal ends of the tubing were extended outside of the animal cage and connected to $5-\mu \mathrm{l}$ Hamilton syringes (Waters Ltd, Elstress, UK), thereby allowing remote infusion without disturbing the animals during the experiment. Rats were attached via one of the two cardiac catheters to a computer-controlled automated blood sampling system, which allows for the intermittent withdrawal of blood samples $(25 \mu \mathrm{l})$ without disturbing the animals. Once connected, animals were left undisturbed for $1 \mathrm{~h}$, after which blood sampling for LH measurement commenced at $\sim 1000 \mathrm{~h}$ and samples were collected every $5 \mathrm{~min}$ for $6 \mathrm{~h}$. After removal of each $25 \mu \mathrm{l}$ blood sample, an equal volume of heparinized saline $(5 \mathrm{U} / \mathrm{ml}$ normal saline; CP Pharmaceuticals Ltd, Wrexham, UK) was automatically infused into the animal to maintain blood volume. For restraint stress, after 100 min of controlled blood sampling, bicuculline, ( $0.2 \mathrm{pmol}$ in $200 \mathrm{nl}$ aCSF for each side; $n=9$ ), CGP-35348 ( $1.5 \mathrm{nmol}$ in $200 \mathrm{nl}$ aCSF for each side; $n=10)$ or aCSF (200 $\mathrm{nl}$ for each side; $n=9$ ) was administered over 5 min via the intra-ARC cannulae. Additional same doses of bicuculline, CGP-35348 or aCSF were given at 20 and $40 \mathrm{~min}$ after the initial injection. Twenty minutes after the initial intra-ARC injection, the rats were placed in custombuilt restraint devices for $1 \mathrm{~h}$. This was necessary since commercially available restraint devices would not be suitable for mobile animals with the head tether attachment used for the automated blood sampling in the experiment. Automated blood sampling continued uninterrupted during restraint and the 3 -h post-restraint period. Additional controls were left to roam freely around their enclosure after the intra-ARC infusions of aCSF $(n=8)$, bicuculline $(n=9)$ or CGP-35348 $(n=9)$. For the immunological stress, LPS $(25 \mu \mathrm{g} / \mathrm{kg}$ in $0.3 \mathrm{ml}$ saline, SigmaAldrich) was injected via the second i.v. catheter $20 \mathrm{~min}$ after the first intra-ARC injection of bicuculline $(n=10)$, CGP-35348 $(n=10)$ or aCSF $(n=9)$. Two additional injections of the drug were given at 20 and 40 min after the initial injection. Control rats were given bilateral intraARC injections of aCSF $(n=8)$, bicuculline $(n=9)$ or CGP$35348(n=8)$ followed by injection of $0.3 \mathrm{ml}$ of saline instead of LPS.

Published by Bioscientifica Ltd. 
For CRF experiment, rats were prepared following the procedure as described for the stress experiments. At the same time, an i.c.v. internal cannula (Plastics One) with extension tubing, preloaded with CRF or aCSF, was inserted into the unilateral guide cannula. The distant end of the tubing connected to the i.c.v. cannula was extended outside of the animal cage and attached to a 25- $\mu$ l Hamilton syringe (Waters Ltd). Blood sampling continued for $6 \mathrm{~h}$. Bicuculline $(0.2 \mathrm{pmol} ; n=11)$, CGR35348 ( $1.5 \mathrm{nmol} ; n=11)$ or aCSF $(0.2 \mu \mathrm{l} ; n=10)$ was bilaterally administered into the ARC as described for the stress experiments. Twenty minutes after the first injection into the ARC, CRF ( $1 \mathrm{nmol}$ in $4 \mu \mathrm{laCSF}$ ) was infused i.c.v. over a period of $5 \mathrm{~min}$. Additional control rats were given bilateral intra-ARC injections of aCSF $(n=8)$, bicuculline $(n=10)$ or CGP-35348 $(n=9)$, with the same doses and procedures, followed by i.c.v. injection of $4 \mu \mathrm{l}$ aCSF.

\section{ARC cannula placement}

Correct cannula placement in the ARC was confirmed by injection of $200 \mathrm{nl}$ India ink through the internal guide cannula, followed by cresyl violet staining and microscopic inspection of $30-\mu \mathrm{m}$ frozen brain sections. Only data from animals with correct cannula placement was analyzed.

\section{RIA for LH measurement}

A double-antibody RIA supplied by the National Institute of Diabetes and Digestive and Kidney Diseases (NIDDK, Bethesda, MD, USA) was used to determine the LH concentration in the $25-\mu 1$ whole blood sample. Reference preparation was rLH-RP-3. The sensitivity of the assay was $0.093 \mathrm{ng} / \mathrm{ml}$. The intra-assay variation was $6.8 \%$, and the inter-assay variation was $8.0 \%$.

\section{Statistical analysis}

The algorithm ULTRA was used to establish the detection of LH pulses (Van Cauter 1988). Two intra-assay coefficients of variation of the assay were used as the reference threshold for the pulse detection. Briefly, ULTRA functions by comparing each data point to the two points before and after, and determining if a significant rise and fall has occurred in the profile; this is consistent with a pulse. The inhibitory effect of LPS stress or i.c.v. infusion of CRF on pulsatile LH secretion was calculated by comparing the mean LH pulse interval before treatment with that during the first $2 \mathrm{~h}$ post-LPS or CRF administration. Additionally, the mean LH pulse interval during the 3rd plus 4 th $\mathrm{h}$ post- LPS or CRF treatment period was compared with the 2 -h baseline control period. The inhibitory effect of restraint stress on LH pulses was calculated by comparing the mean LH pulse interval before stress with the first prolonged interval, which corresponded to the first LH pulse interval, after stress onset. For the 2-h pre-restraint baseline and post-restraint recovery periods, the LH interpulse interval was calculated by dividing the appropriate period duration by the number of pulses. In the absence of stressors or CRF infusion, the LH interpulse intervals within the corresponding time periods were compared. Statistical significance was tested using one-way repeated measures ANOVA followed by Dunnett's test. $P<0.05$ was considered statistically significant.

\section{Results}

\section{Correct ARC cannula placement}

Figure 1 shows the location of individual bilateral cannula that was targeted in the ARC, as well as misplaced injection sites. Data from animals with incorrect cannula placement were analyzed separately.

\section{Effects of intra-ARC infusion of bicuculline or CGP-35348 on restraint stress-induced suppression of $\mathrm{LH}$ pulses}

In the restraint stress experiments, there was no significant difference between the LH pulse interval within the 2-h baseline period of control $(n=6)$ and restrained $(n=7)$ rats receiving aCSF, with group means \pm s.E.M. of $21.11 \pm 0.51$ and $24.31 \pm 0.87 \mathrm{~min}$ respectively (Fig. 2A, B and G). Restraint stress resulted in an immediate interruption of pulsatile LH secretion in aCSF-treated animals (Fig. 2B and $\mathrm{G} ; P<0.05)$. Bilateral intra-ARC administration of $\mathrm{GABA}_{\mathrm{B}} \mathrm{R}$ antagonist, CGP-35348 (Fig. $2 \mathrm{~F}$ and G; $n=8 ; P<0.05$ ) but not $\mathrm{GABA}_{\mathrm{A}} \mathrm{R}$ antagonist, bicuculline (Fig. $2 \mathrm{D}$ and $\mathrm{G} ; n=7$; $P=0.84$ ) $20 \mathrm{~min}$ before the onset of restraint stress and at 20 and $40 \mathrm{~min}$ after the initial injection significantly reduced restraint stress-induced suppression of LH pulses. Intra-ARC administration of bicuculline $(n=7)$ or CGP$35348(n=7)$ per se had no effect on LH pulse frequency (Fig. 2, C, E and G).

The data from rats with incorrect cannula placement were analyzed separately. The restraint stress-induced suppression of LH pulses was not attenuated by the administration of CGP-35348 $(n=2)$ or bicuculline $(n=2)$, with group means \pm s.e.m. of $52.50 \pm 7.50$ and

Published by Bioscientifica Ltd 
A

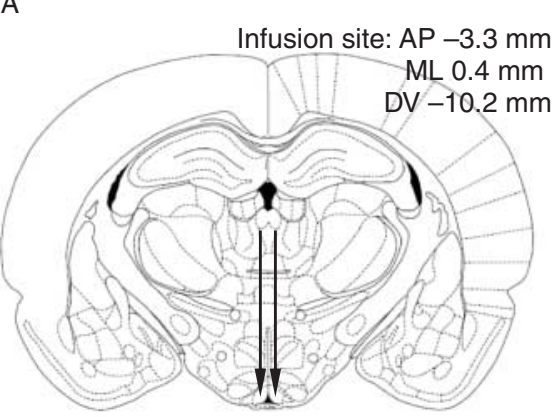

B

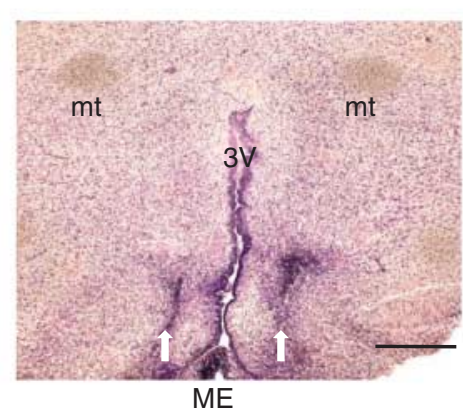

C Restraint stress
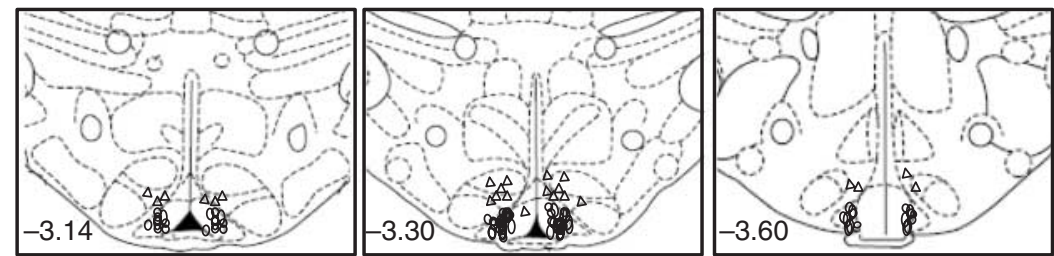

D

LPS stress
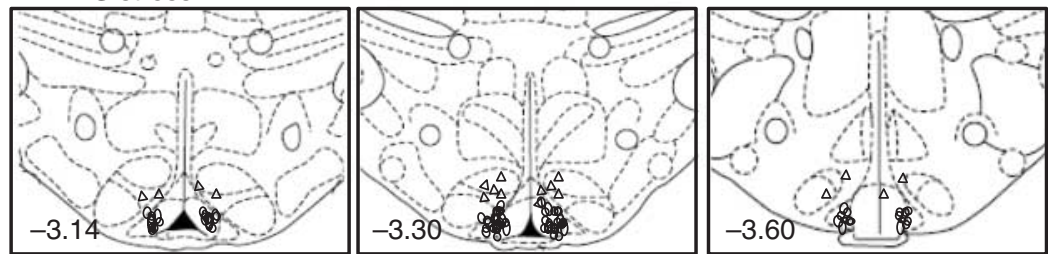

E

Centrally administrated CRF

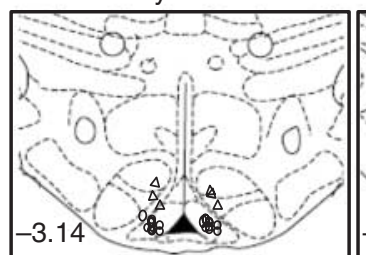

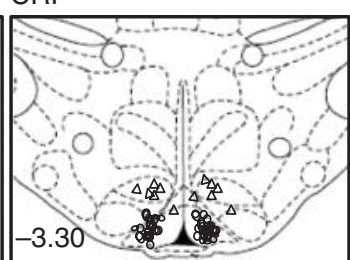

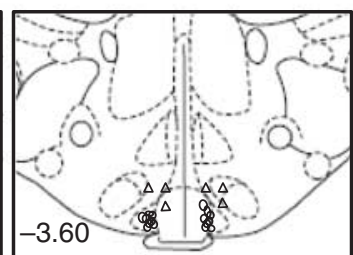

\section{Figure 1}

Schematic illustration and photomicrograph of the infusion site targeted to the arcuate nucleus (ARC). (A and B) Schematic illustration and photomicrograph showing the target site for bilateral cannulation of the ARC. Bars, $500 \mu \mathrm{m}$. (C, D and E) Schematic drawings of the ARC illustrating the individual sites of injection for the restraint, LPS stress or CRF infusion

$52.50 \pm 2.50 \mathrm{~min}$ for the first prolonged LH pulse interval post restraint stress, respectively.

\section{Effects of bicuculline or CGP-35348 on LPS stress-induced suppression of LH pulses}

For the systemic stress experiments, in the 2-h basal control period, no differences in $\mathrm{LH}$ pulse interval were detected between the aCSF- $(n=7)$, bicuculline- $(n=8)$ or CGP-35348- $(n=6)$ treated animals with saline co-injection (Fig. 3A, C, E and G). Administration of LPS (25 $\mu \mathrm{g} / \mathrm{kg}$ in $0.3 \mathrm{ml}$, i.v.) into aCSF-treated rats evoked a profound inhibitory effect on pulsatile LH release, which was observed after a delay of $\sim 30$ min with the first prolonged LH pulse interval lasting more than $1 \mathrm{~h}$, followed by a general recovery to normal LH pulse frequency (Fig. 3B and G; $n=7 ; P<0.05)$. The animals treated with bicuculline demonstrated an attenuated $\mathrm{LH}$ pulse suppression in response to LPS stress (Fig. 3D and G; $n=9 ; P<0.05$ ), with a group mean \pm s.e.M. of $31.14 \pm 2.02 \mathrm{~min}$ for the $\mathrm{LH}$ pulse interval in the first $2 \mathrm{~h}$ following injection of LPS; this was not observed in the animals treated with CGP-35348 experiments respectively. Numbers in each drawing indicate the distance $(\mathrm{mm})$ to bregma. Open circles show the injection sites, open triangles show the misplaced injection sites. $\mathrm{mt}$, mammillothalamic tract; 3V, third ventricle; ME, median eminence.

(Fig. $3 F$ and $\mathrm{G} ; n=8 ; P=0.11$ ), with a group mean \pm s.E.M. of $50.63 \pm 5.02 \mathrm{~min}$ for the $\mathrm{LH}$ pulse interval in the same period. The administration of saline $(0.3 \mathrm{ml}$, i.v.) had no effect on the $\mathrm{LH}$ pulse interval in animals treated with aCSF (Fig. 3A and G), bicuculline (Fig. 3C and $G$ ) or CGP-35348 (Fig. 3E and G). LPS induced similar suppression of LH pulses in one bicuculline-treated rats and two CGP-35348-treated rats that had cannulae located outside the ARC.

\section{Effects of bicuculline or CGP-35348 on CRF-induced suppression of LH pulses}

In the 2-h basal control period, no differences in LH pulse interval were observed in rats infused with aCSF vehicle $(n=8)$, bicuculline $(n=9)$ or CGP-35348 $(n=9)$ into the ARC with centrally administrated CRF, with group means \pm s.E.M. of $22.50 \pm 0.84,23.33 \pm 1.13$ and $23.61 \pm$ 1.35 min, respectively (Fig. 4B, D, F and G). Administration of CRF ( 1 nmol, i.c.v.) increased the $\mathrm{LH}$ release interval (Fig. 4B and G; $P<0.05$ ). Bilateral intra-ARC administration of either bicuculline (Fig. 4D and G;

Published by Bioscientifica Ltd. 

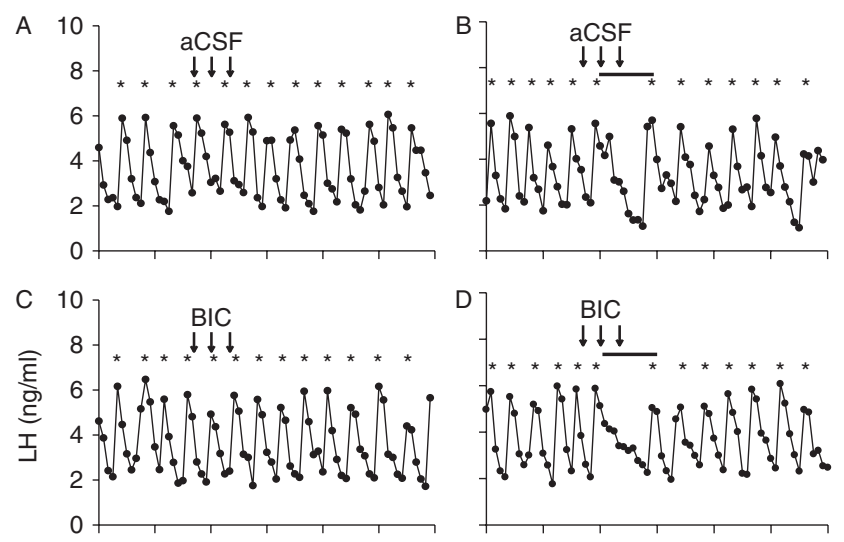

E 10
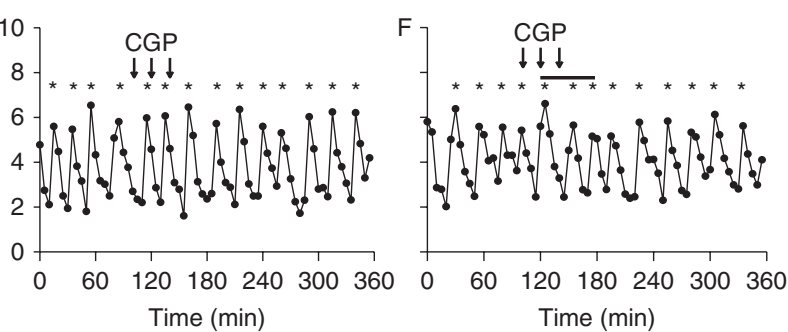

Figure 2

Representative examples illustrating the effect of intra-ARC administration of bicuculline (BIC) or CGP-35348 (CGP), on restraint stress-induced suppression of LH pulses in ovx, $E_{2}$-treated rats. Representative examples showing effects of bilateral intra-ARC infusion (down arrow) of aCSF ( $A$ and $B$ ), BIC (C and D) or CGP ( $E$ and $F$ ) on LH pulse frequency in the

$P<0.05$ ) or CGP-35348 (Fig. $4 \mathrm{~F}$ and G; $P<0.05$ ) significantly reduced the inhibitory effect of CRF on pulsatile LH release. No significant differences were found between the effect of bicuculline or CGP-35348 on the attenuation of the suppression of LH pulses in response to CRF (Fig. 4D, F and G; $P=0.53$ ). The i.c.v. administration of aCSF had no effect on the LH pulse interval in animals treated with intra-ARC injection of aCSF (Fig. $4 \mathrm{~A}$ and $\mathrm{G} ; n=6$ ), bicuculline (Fig. 4C and G; $n=8$ ) or CGP-35348 (Fig. 4E and $\mathrm{G} ; n=7$ ).

CRF induced a similar suppression of LH pulses in two bicuculline and two CGP-35348-treated rats in which the cannulae were located outside the ARC, with groups mean \pm s.E.M. of $46.50 \pm 3.50$ and $47.50 \pm 6.50 \mathrm{~min}$ for $\mathrm{LH}$ pulse interval in the first $2 \mathrm{~h}$ post injection of CRF respectively.

\section{Discussion}

The present study not only shows that endogenous GABA signaling within the ARC mediates stress-induced suppression of GnRH pulse generator, but also provides evidence for a stressor-specific manner of GABA receptor subtypes in

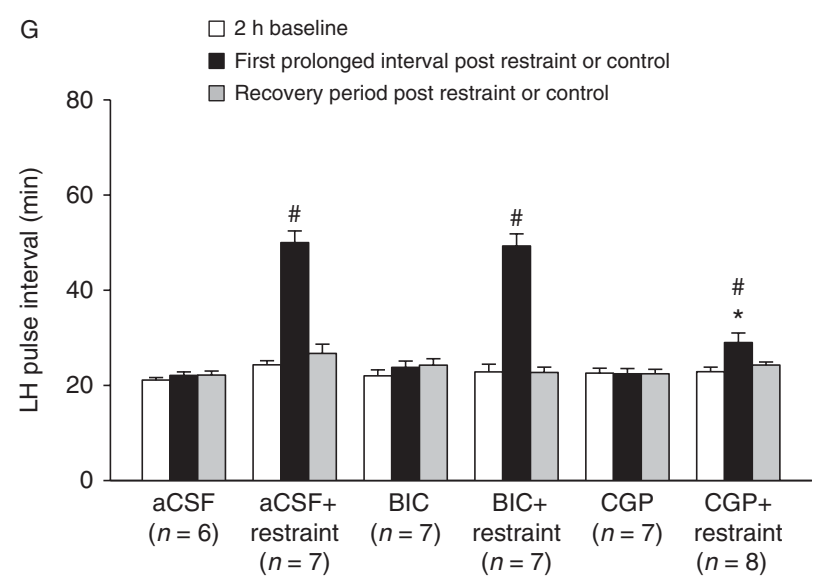

absence and presence (horizontal line; $1 \mathrm{~h}$ ) of restraint stress, respectively. (G) Summary showing the effect of intra-ARC infusion of selective GABA receptor subtype antagonists on restraint stress-induced suppression of pulsatile $\mathrm{LH}$ secretion. ${ }^{\#} P<0.05$ vs pre-restraint control period within the same group. ${ }^{*} P<0.05$ vs restrained controls at the same time point.

the regulation of the GnRH pulse generator. We found that administration of the selective $\mathrm{GABA}_{\mathrm{A}} \mathrm{R}$ antagonist, bicuculline, into the ARC markedly attenuated the inhibitory effect of LPS, but not restraint stress on pulsatile LH secretion. In contrast, restraint but not LPS stressinduced suppression of LH pulse frequency was reversed by intra-ARC infusion of the specific $\mathrm{GABA}_{\mathrm{B}} \mathrm{R}$ antagonist, CGP-35348. This is consistent with the evidence showing that various stressors, including restraint and LPS, increase GABAergic activity in the ARC (Bowers et al. 1998, Akema et al. 2005, Sirivelu et al. 2009). Consistently, a similar differential role has also been reported for $m P O A G A B A_{A} R$ and $G_{A B A} R$ in various stressors-induced suppression of the pulse generator (Lin et al. 2012). In the present study, the radius of spread of dye from the centre of the injection site in the ARC was $\sim 400 \mu \mathrm{m}$ (data not shown), making sure that the GABA antagonist is limited with the ARC region but not reach other critical stress-related sites such as mPOA (Herbison et al. 1995, Lohman et al. 2005, Lin et al. 2012). It is further supported by the evidence showing that perfusion of GABA antagonists via misplaced ARC cannulae was ineffective in blocking the inhibitory responses. 

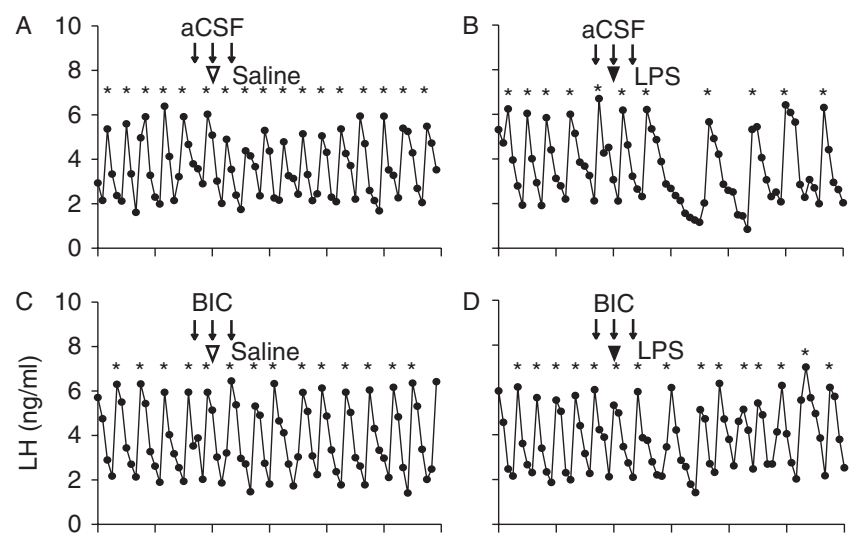

E
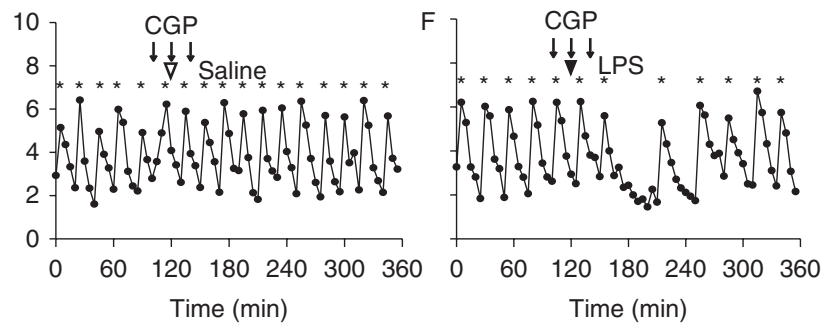

\section{Figure 3}

Representative examples illustrating the effect of intra-ARC administration of $G_{A B A}$ receptor antagonist, bicuculline $(B I C)$ or $G_{A B} A_{B}$ receptor antagonist, CGP-35348 (CGP), on LPS stress-induced suppression of pulsatile $\mathrm{LH}$ secretion in ovx, $\mathrm{E}_{2}$-treated rats. Representative examples showing effects of bilateral intra-ARC infusion (down arrow) of aCSF (A and B), BIC $(C$ and $D)$ or CGP (E and F) on LH pulse frequency in animals injected saline

A stressor-specific property of GABA receptor subtypes in the regulation of the GnRH pulse generator has been demonstrated in the present study. Consistently, previous studies have shown that $\mathrm{GABA}_{\mathrm{A}} \mathrm{R}$ antagonist, bicuculline blocks IL-1 $\beta$ (Sirivelu et al. 2009) but not restraint (Roozendaal et al. 1997) stress-induced suppression of preovulatory $\mathrm{LH}$ surge. On the other hand, the $\mathrm{GABA}_{\mathrm{B}} \mathrm{R}$ antagonist, CGP-35348, is without effect on systemic stress response (Sirivelu et al. 2009). Moreover, $\mathrm{GABA}_{\mathrm{B}} \mathrm{R}$ has been reported to be involved in psychogenic disorders like anxiety and depression (Nakagawa et al. 1996, Nowak et al. 2006). Nevertheless, the physiological significance of the differential effects of the GABA receptor subtypes observed in the present and previous study remains to be unknown. The identification of the ARC as a common site for GABA receptor modulation of restraint and LPS might suggest a convergence of pathways that are activated by different types of stressors, including psychological and immunological, which is similar to our previous observation with the region of mPOA (Lin et al. 2012). It is worth noting that the suppressive effect of LPS and

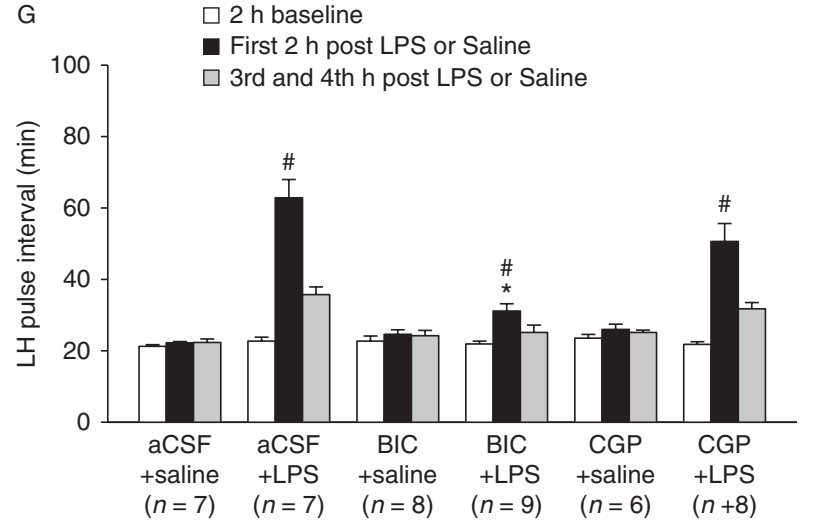

$(0.3 \mathrm{ml}$; down-headed open triangle) or LPS $(25 \mu \mathrm{g} / \mathrm{kg}$, in $0.3 \mathrm{ml}$ saline; down-headed filled triangle) respectively. (G) Summary showing the effect of intra-ARC infusion of specific GABA receptor subtype antagonists on LPS stress-induced suppression of pulsatile LH secretion. ${ }^{\#} P<0.05$ vs pre-LPS control period within the same group. ${ }^{*} P<0.05$ vs LPS-treated controls at the same time point.

restraint on pulsatile $\mathrm{LH}$ secretion was not completely blocked by intra-ARC administration of the selective GABA receptor antagonists, raising the possibility that the GABAergic signalling within the ARC might just play a partial role in stress-induced suppression of GnRH pulse frequency.

Our previous study demonstrated that endogenous GABA signaling within the MPOA is involved in the stressinduced suppression of LH pulses, indicating the direct actions of GABA on GnRH neurons (Lin et al. 2012), since the GnRH soma are located in the mPOA. Although no GnRH neurons are observed in the ARC region in the rat (Merchenthaler et al. 1984), recent neuroanatomical studies demonstrated that GABAergic inputs heavily contact the entire length of GnRH dendron which include dentrite and axon in the arcuate-median eminence region (Campbell et al. 2005, Herde et al. 2013, Moore et al. 2015), indicating that the GABA may also act directly on GnRH dendrons in the mediation of LH pulses during stress. Additionally, as the critical excitatory player in the control of GnRH pulse generator activity (Goodman et al. 2007,

Published by Bioscientifica Ltd. 

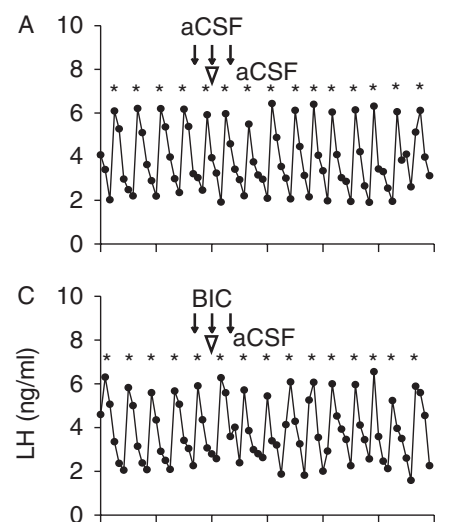

E

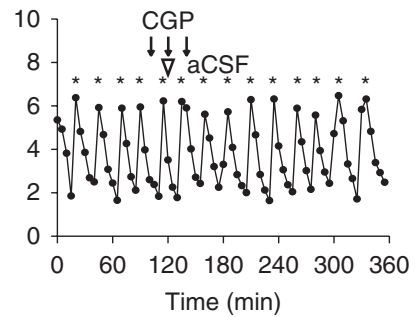

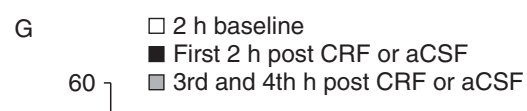
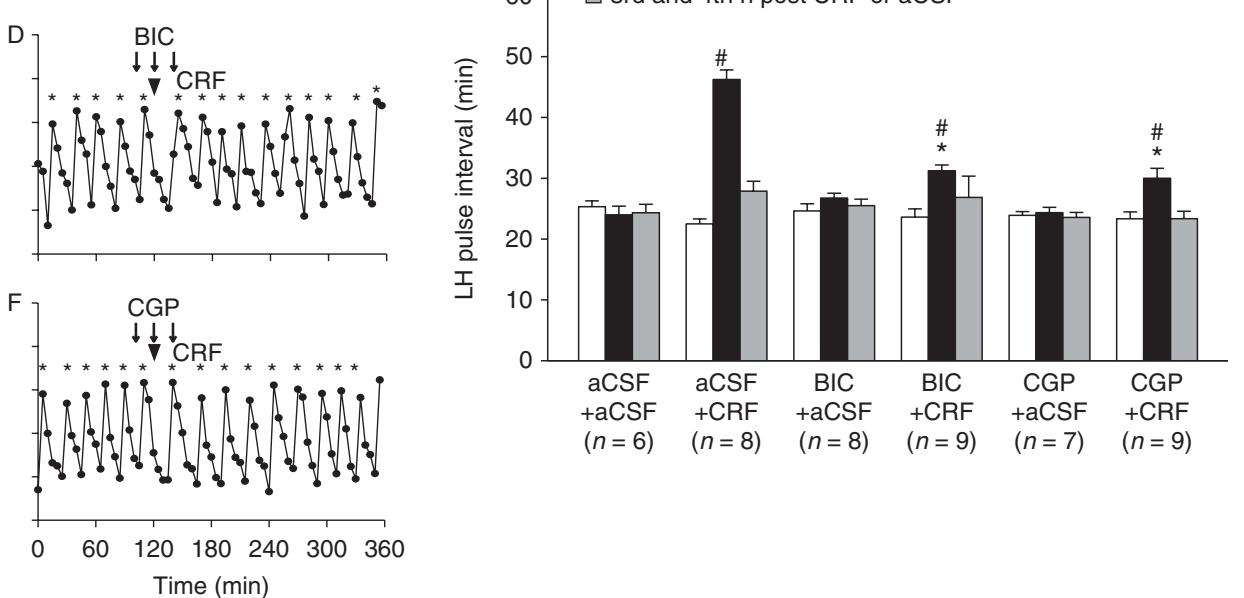

Figure 4

Representative examples illustrating the effect of intra-ARC administration of $\mathrm{GABA}_{A}$ receptor antagonist, bicuculline $(\mathrm{BIC})$ or $\mathrm{GABA}_{B}$ receptor antagonist, CGP-35348 (CGP) on CRF-induced suppression of pulsatile LH secretion in ovx, $E_{2}$-treated rats. Representative examples showing effects of bilateral intra-mPOA infusion (down arrow) of aCSF (A and B), BIC ( $C$ and $D$ ) or CGP ( $E$ and $F$ ) on LH pulse frequency in animals injected with

Li et al. 2009), kisspeptin neuronal system in the ARC is down-regulated by central administration of CRF and by various stressors, including restraint, LPS and hypoglycaemic stress (Kinsey-Jones et al. 2009, Castellano et al. 2010), suggesting a reduced kisspeptin system may be a contributing factor in stress-induced suppression of GnRH pulse generator frequency. However, the mechanisms causing the stress-induced decrease of kisspeptin remain to be explored. One recent study demonstrated a functional relationship between the kisspeptin and GABAergic neuronal network by showing that blockage of endogenous GABAergic signalling with bicuculline dramatically increases kisspeptin release (Terasawa et al. 2010). Therefore, GABAergic signalling might, in part, suppress the kisspeptin neuronal network in the ARC, and thereby GnRH pulse generator activity, during stress.

It is well established that CRF plays a pivotal role in stress-induced suppression of pulsatile LH secretion in various species (Li et al. 2010). Although the synaptic connections between CRF and GnRH neurons are observed in the MPOA of rats (MacLusky et al. 1988), providing the anatomical substrate for direct functional interaction between CRF and GnRH neurons; the failure to

aCSF ( $4 \mu \mathrm{l}$; down-headed open triangle) or CRF ( $1 \mathrm{nmol}$ in $4 \mu \mathrm{l}$ aCSF; down-headed filled triangle) respectively. (G) Summary showing the effect of intra-ARC infusion of selective GABA receptor subtype antagonists on CRF-induced suppression of pulsatile LH secretion. ${ }^{~} P<0.05$ vs pre-CRF control period within the same group. ${ }^{*} P<0.05$ vs CRF-treated controls at the same time point.

find any back-filled CRF cells from major CRF populations to GnRH perikarya using tract-tracing in rats (Hahn et al. 2003) suggests that CRF-mediated suppression of GnRH pulse generator frequency may primarily involve indirect regulatory mechanisms. The present data, showing that infusion of GABA receptor antagonist into the ARC blocked the inhibitory effect of i.c.v. administrated CRF on pulsatile LH secretion, indicates that GABAergic signaling within the ARC regions may be lower in the functional hierarchy to CRF in regulating GnRH pulse generator activity. Although whether GABAergic neurons in the $\mathrm{mPOA}$ receive direct $\mathrm{CRF}$ inputs has not been examined, CRF is demonstrated to augment the postsynaptic response to GABA via increasing GABA release in other brain regions, including the central nucleus of amygdala and bed nucleus of stria terminalis (Kash \& Winder 2006, Roberto et al. 2010). Nevertheless, the possibility of direct actions of CRF at the level of the GnRH or GABA cell bodies could not be excluded, since infusion of CRF directly into ARC has been observed to suppress pulsatile LH secretion in ovx, $\mathrm{E}_{2}$-primed rats (Li et al. 2010). This observation extends the studies demonstrating that the opioidergic signaling acts as a

Published by Bioscientifica Ltd. 
downstream player to CRF in stress-induced suppression of GnRH pulse generator activity.

Although the main focus of the present study was to determine the role of the ARC GABAergic receptor signaling in the stress-induced suppression of pulsatile LH secretion, an inevitable adjunct was the effects of manipulating GABA signaling on GnRH pulse generator frequency per se. We have shown in the present study that intra-ARC administration of $\mathrm{GABA}_{\mathrm{A}} \mathrm{R}$ or $\mathrm{GABA}_{\mathrm{B}} \mathrm{R}$ antagonists at doses that block stress-induced suppression of $\mathrm{LH}$ pulses do not affect pulsatile LH secretion per se, suggesting that GABAergic signaling in the ARC might not be critical for regulation of $\mathrm{GnRH}$ pulse generator frequency under normal non-stress conditions. However, this suggestion has to be tempered because there is considerable evidence that the gonadal steroid milieu modulates GABAergic control of GnRH/LH secretion (Scott \& Clarke 1993b). Indeed, dioestous-like levels of $\mathrm{E}_{2}$ replacement (Cagampang et al. 1991) were used in the present study to provide an enhanced preoptic GABA tone compared to an ovariectomised alone model (Mansky et al. 1982), so the results might have been different with the use of an alternative gonadal steroid replacement regimen or an intact rat model. Although some studies reported the inhibitory effect of $\mathrm{GABA}_{\mathrm{A}} \mathrm{R}$ antagonism with bicuculline on GnRH pulse generator frequency, it is possibly a consequence of CNS disturbances, at least in the rat (Kimura et al. 1993). It is further supported by evidence showing that a $70-90 \%$ reduction in the levels of $\mathrm{GABA}_{\mathrm{A}} \mathrm{R}$ activity at the GnRH neuron after knockdown of the $\gamma 2$ subunit in these neurons did not affect basal levels of LH or fertility in the mouse (Lee et al. 2010). With regard to $\mathrm{GABA}_{\mathrm{B}} \mathrm{R}$ antagonism in the ARC, we similarly failed to demonstrate an effect on pulsatile LH secretion, confirming observations in the sheep (Scott \& Clarke 1993b). Thus, based on the preceding results, it appears that GABAergic signaling per se are not involved in the normal regulation of LH pulses under nonstressed conditions, but nonetheless their activation under stressful conditions consequently inhibits GnRH pulse generator activity.

The present study and our previous study demonstrate the role of GABA signaling in the ARC and mPOA in stressinduced suppression of $\mathrm{LH}$ pulses respectively. As the essential sites involving reproductive function, there is no reason to exclude the possibility that either the MPOA or the ARC might contribute to the modulation of pulsatile LH secretion under stressful conditions. Indeed, electrochemical stimulation of both the MPOA and ARC has been shown to affect LH release in rats (Kawakami et al. 1982). Moreover, CRF can act on both the mPOA and ARC to inhibit pulsatile LH secretion in rats (Li et al. 2010). The consistent results regarding a role for the endogenous GABAergic system in the MPOA and ARC in the mediation of the LH pulse frequency during stress, presented in the pharmacological studies, emphasis that both regions may act as major sites involving stress-induced suppression of GnRH pulse generator frequency. In addition to the communication at the level of the median eminence that fibers originating in the ARC are shown to innervate $\mathrm{GnRH}$ fibers arising within the MPOA (Ramaswamy et al. 2008), the ARC also provides an direct or indirect route to $\mathrm{GnRH}$ perikarya within the mPOA (Pompolo et al. 2005, Wintermantel et al. 2006). Therefore, it is reasonable to speculate that the mPOA and ARC might not act independently but interact with each other in the modulation of GnRH pulse generator activity during stress.

Taken together, the results of this study indicate a pivotal and differential role of endogenous $G_{A B A} R$ and $\mathrm{GABA}_{\mathrm{B}} \mathrm{R}$ signaling mechanisms in the ARC with respect to mediating immunological and psychological stressinduced suppression of the GnRH pulse generator respectively. Moreover, this observation demonstrates that the GABAergic signaling acts as a downstream player to CRF in stress-induced suppression of GnRH pulse generator activity. Nevertheless, more studies need to be conducted to characterize the mechanisms by which stress inhibits the GnRH pulse generator.

\section{Declaration of interest}

The authors declare that there is no conflict of interest that could be perceived as prejudicing the impartiality of the research reported.

\section{Funding}

This study was supported by the National Natural Science Foundation of China (81301014), Foundation of Wenzhou Science and Technology Bureau (Y20140273) and Zhejiang Provincial Key Discipline-Neurobiology (437201203).

\section{Acknowledgements}

The authors thank Dr James Kinsey-Jones for expert technical assistance in carrying out animal surgeries.

\section{References}

Akema T, He D \& Sugiyama H 2005 Lipopolysaccharide increases $\gamma$-aminobutyric acid synthesis in medial preoptic neurones in association with inhibition of steroid-induced luteinising hormone surge in female rats. Journal of Neuroendocrinology 17 672-678. (doi:10.1111/j.1365-2826.2005.01358.x)

Published by Bioscientifica Ltd. 
Anderson RA \& Mitchell R 1986 Effects of $\gamma$-aminobutyric acid receptor agonists on the secretion of growth hormone, luteinizing hormone, adrenocorticotrophic hormone and thyroid-stimulating hormone from the rat pituitary gland in vitro. Journal of Endocrinology 108 1-8. (doi:10.1677/joe.0.1080001)

Bowers G, Cullinan WE \& Herman JP 1998 Region-specific regulation of glutamic acid decarboxylase (GAD) mRNA expression in central stress circuits. Journal of Neuroscience 18 5938-5947.

Cagampang FR, Maeda KI, Tsukamura H, Ohkura S \& Ota K 1991 Involvement of ovarian steroids and endogenous opioids in the fastinginduced suppression of pulsatile LH release in ovariectomized rats. Journal of Endocrinology 129 321-328. (doi:10.1677/joe.0.1290321)

Campbell RE, Han SK \& Herbison AE 2005 Biocytin filling of adult gonadotropin-releasing hormone neurons in situ reveals extensive, spiny, dendritic processes. Endocrinology 146 1163-1169. (doi:10.1210/ en.2004-1369)

Castellano JM, Bentsen AH, Romero M, Pineda R, Ruiz-Pino F, Garcia-Galiano D, Sanchez-Garrido MA, Pinilla L, Mikkelsen JD \& Tena-Sempere M 2010 Acute inflammation reduces kisspeptin immunoreactivity at the arcuate nucleus and decreases responsiveness to kisspeptin independently of its anorectic effects. American Journal of Physiology. Endocrinology and Metabolism 299 E54-E61. (doi:10.1152/ ajpendo.00081.2010)

Decavel C \& van den Pol AN 1990 GABA: a dominant neurotransmitter in the hypothalamus. Journal of Comparative Neurology 302 1019-1037. (doi:10.1002/cne.903020423)

Feleder C, Refojo D, Jarry H, Wuttke W \& Moguilevsky JA 1996 Bacterial endotoxin inhibits LHRH secretion following the increased release of hypothalamic GABA levels. Different effects on amino acid neurotransmitter release. Neuroimmunomodulation 3 342-351. (doi:10.1159/ 000097294)

Ferreira SA, Scott CJ, Kuehl DE \& Jackson GL 1996 Differential regulation of luteinizing hormone release by $\gamma$-aminobutyric acid receptor subtypes in the arcuate-ventromedial region of the castrated ram. Endocrinology 137 3453-3460. (doi:10.1210/endo.137.8.8754774)

Ferreira SA, Hileman SM, Kuehl DE \& Jackson GL 1998 Effects of dialyzing $\gamma$-aminobutyric acid receptor antagonists into the medial preoptic and arcuate ventromedial region on luteinizing hormone release in male sheep. Biology of Reproduction 58 1038-1046. (doi:10.1095/biolreprod58.4.1038)

Goodman RL, Lehman MN, Smith JT, Coolen LM, de Oliveira CV, Jafarzadehshirazi MR, Pereira A, Iqbal J, Caraty A, Ciofi P et al. 2007 Kisspeptin neurons in the arcuate nucleus of the ewe express both dynorphin A and neurokinin B. Endocrinology 148 5752-5760. (doi:10.1210/en.2007-0961)

Hahn JD, Kalamatianos T \& Coen CW 2003 Studies on the neuroanatomical basis for stress-induced oestrogen-potentiated suppression of reproductive function: evidence against direct corticotropin-releasing hormone projections to the vicinity of luteinizing hormone-releasing hormone cell bodies in female rats. Journal of Neuroendocrinology $\mathbf{1 5}$ 732-742. (doi:10.1046/j.1365-2826.2003.01056.x)

Herbison AE, Augood SJ, Simonian SX \& Chapman C 1995 Regulation of GABA transporter activity and mRNA expression by estrogen in rat preoptic area. Journal of Neuroscience 15 8302-8309.

Herde MK, Iremonger KJ, Constantin S \& Herbison AE 2013 GnRH neurons elaborate a long-range projection with shared axonal and dendritic functions. Journal of Neuroscience 33 12689-12697. (doi:10.1523/ JNEUROSCI.0579-13.2013)

Hiruma H, Sano A \& Kimura F 1994 Injection of bicuculline elicits firing of luteinizing hormone releasing hormone pulse generator in muscimoltreated ovariectomized rats. Brain Research 641 191-197. (doi:10.1016/ 0006-8993(94)90145-7)

Jackson GL \& Kuehl D 2002 Gamma-aminobutyric acid (GABA) regulation of GnRH secretion in sheep. Reproduction. Supplement 59 15-24.

Kash TL \& Winder DG 2006 Neuropeptide Y and corticotropin-releasing factor bi-directionally modulate inhibitory synaptic transmission in the bed nucleus of the stria terminalis. Neuropharmacology $\mathbf{5 1}$ 1013-1022. (doi:10.1016/j.neuropharm.2006.06.011)

Kash SF, Tecott LH, Hodge C \& Baekkeskov S 1999 Increased anxiety and altered responses to anxiolytics in mice deficient in the $65-\mathrm{kDa}$ isoform of glutamic acid decarboxylase. PNAS 96 1698-1703. (doi:10.1073/ pnas.96.4.1698)

Kawakami M, Uemura T \& Hayashi R 1982 Electrophysiological correlates of pulsatile gonadotropin release in rats. Neuroendocrinology 35 63-67. (doi:10.1159/000123356)

Kimura F, Sano A, Hiruma H \& Funabashi T 1993 Effects of $\gamma$-aminobutyric acid-A receptor antagonist, bicuculline, on the electrical activity of luteinizing hormone-releasing hormone pulse generator in the ovariectomized rat. Neuroendocrinology 57 605-614. (doi:10.1159/ 000126414)

Kinsey-Jones JS, Li XF, Knox AM, Wilkinson ES, Zhu XL, Chaudhary AA, Milligan SR, Lightman SL \& O'Byrne KT 2009 Down-regulation of hypothalamic kisspeptin and its receptor, Kiss1r, mRNA expression is associated with stress-induced suppression of luteinising hormone secretion in the female rat. Journal of Neuroendocrinology 21 20-29. (doi:10.1111/j.1365-2826.2008.01807.x)

Lee K, Porteous R, Campbell RE, Luscher B \& Herbison AE 2010 Knockdown of GABA(A) receptor signaling in GnRH neurons has minimal effects upon fertility. Endocrinology 151 4428-4436. (doi:10.1210/en.2010-0314)

Li XF, Kinsey-Jones JS, Cheng Y, Knox AM, Lin Y, Petrou NA, Roseweir A, Lightman SL, Milligan SR, Millar RP et al. 2009 Kisspeptin signalling in the hypothalamic arcuate nucleus regulates GnRH pulse generator frequency in the rat. PLOS ONE 4 e8334. (doi:10.1371/journal.pone. 0008334)

Li XF, Knox AM \& O'Byrne KT 2010 Corticotrophin-releasing factor and stress-induced inhibition of the gonadotrophin-releasing hormone pulse generator in the female. Brain Research 1364 153-163. (doi:10.1016/j.brainres.2010.08.036)

Li XF, Lin YS, Kinsey-Jones JS, Milligan SR, Lightman SL \& O’Byrne KT 2011 The role of the bed nucleus of the stria terminalis in stress-induced inhibition of pulsatile luteinising hormone secretion in the female rat. Journal of Neuroendocrinology 23 3-11. (doi:10.1111/j.1365-2826.2010. 02071.x)

Lin Y, Li X, Lupi M, Kinsey-Jones JS, Shao B, Lightman SL \& O’Byrne KT 2011 The role of the medial and central amygdala in stress-induced suppression of pulsatile LH secretion in female rats. Endocrinology 152 545-555. (doi:10.1210/en.2010-1003)

Lin YS, Li XF, Shao B, Hu MH, Goundry AL, Jeyaram A, Lightman SL \& O'Byrne KT 2012 The role of GABAergic signalling in stress-induced suppression of gonadotrophin-releasing hormone pulse generator frequency in female rats. Journal of Neuroendocrinology 24 477-488. (doi:10.1111/j.1365-2826.2011.02270.x)

Lohman RJ, Liu L, Morris M \& O'Brien TJ 2005 Validation of a method for localised microinjection of drugs into thalamic subregions in rats for epilepsy pharmacological studies. Journal of Neuroscience Methods 146 191-197. (doi:10.1016/j.jneumeth.2005.02.008)

MacLusky NJ, Naftolin F \& Leranth C 1988 Immunocytochemical evidence for direct synaptic connections between corticotrophin-releasing factor (CRF) and gonadotrophin-releasing hormone ( $\mathrm{GnRH})$-containing neurons in the preoptic area of the rat. Brain Research 439 391-395. (doi:10.1016/0006-8993(88)91501-6)

Mansky T, Mestres-Ventura P \& Wuttke W 1982 Involvement of GABA in the feedback action of estradiol on gonadotropin and prolactin release: hypothalamic GABA and catecholamine turnover rates. Brain Research 231 353-364. (doi:10.1016/0006-8993(82)90372-9)

Masotto C, Wisniewski G \& Negro-Vilar A 1989 Different $\gamma$-aminobutyric acid receptor subtypes are involved in the regulation of opiatedependent and independent luteinizing hormone-releasing hormone secretion. Endocrinology 125 548-553. (doi:10.1210/endo-125-1-548)

Merchenthaler I, Thomas CR \& Arimura A 1984 Immunocytochemical localization of growth hormone releasing factor (GHRF)-containing 
structures in the rat brain using anti-rat GHRF serum. Peptides 5 1071-1075. (doi:10.1016/0196-9781(84)90173-6)

Mitsushima D, Tin-Tin WS \& Kimura F 2003 Sexual dimorphism in the GABAergic control of gonadotropin release in intact rats. Neuroscience Research 46 399-405. (doi:10.1016/S0168-0102(03)00099-3)

Moore AM, Prescott M, Marshall CJ, Yip SH \& Campbell RE 2015 Enhancement of a robust arcuate GABAergic input to gonadotropinreleasing hormone neurons in a model of polycystic ovarian syndrome. PNAS 112 596-601. (doi:10.1073/pnas.1415038112)

Muroya S, Funahashi H, Uramura K, Shioda S \& Yada T 2005 Gamma aminobutyric acid regulates glucosensitive neuropeptide $\mathrm{Y}$ neurons in arcuate nucleus via A/B receptors. Neuroreport 16 897-901. (doi:10.1097/00001756-200506210-00005)

Nakagawa Y, Ishima T, Ishibashi Y, Yoshii T \& Takashima T 1996 Involvement of $\mathrm{GABA}(\mathrm{B})$ receptor systems in action of antidepressants: baclofen but not bicuculline attenuates the effects of antidepressants on the forced swim test in rats. Brain Research 709 215-220. (doi:10.1016/0006-8993(95)01273-7)

Nishihara M \& Kimura F 1987 Roles of $\gamma$-aminobutyric acid and serotonin in the arcuate nucleus in the control of prolactin and luteinizing hormone secretion. Japanese Journal of Physiology 37 955-961. (doi:10.2170/jjphysiol.37.955)

Nowak G, Partyka A, Palucha A, Szewczyk B, Wieronska JM, Dybala M, Metz M, Librowski T, Froestl W, Papp M et al. 2006 Antidepressant-like activity of CGP 36742 and CGP 51176, selective GABAB receptor antagonists, in rodents. British Journal of Pharmacology 149 581-590. (doi:10.1038/sj.bjp.0706845)

Ohkura S, Tsukamura H \& Maeda K 1991 effects of various types of hypothalamic deafferentation on luteinizing hormone pulses in ovariectomized rats. Journal of Neuroendocrinology 3 503-508. (doi:10.1111/j.1365-2826.1991.tb00310.x)

Paxinos G \& Watson C 1998 Stereotaxic reference system. In The Rat Brain in Stereotaxic Coordinates, 4 edn, pp 30-36. Eds G Paxinos \& C Watson. London, UK: Academic Press.

Plant TM, Krey LC, Moossy J, McCormack JT, Hess DL \& Knobil E 1978 The arcuate nucleus and the control of gonadotropin and prolactin secretion in the female rhesus monkey (Macaca mulatta). Endocrinology 102 52-62. (doi:10.1210/endo-102-1-52)

Pompolo S, Ischenko O, Pereira A, Iqbal J \& Clarke IJ 2005 Evidence that projections from the bed nucleus of the stria terminalis and from the lateral and medial regions of the preoptic area provide input to gonadotropin releasing hormone (GNRH) neurons in the female sheep brain. Neuroscience 132 421-436. (doi:10.1016/j.neuroscience. 2004.12.042)

Ramaswamy S, Guerriero KA, Gibbs RB \& Plant TM 2008 Structural interactions between kisspeptin and GnRH neurons in the mediobasal hypothalamus of the male rhesus monkey (Macaca mulatta) as revealed by double immunofluorescence and confocal microscopy. Endocrinology 149 4387-4395. (doi:10.1210/en.2008-0438)

Rivier C \& Vale W 1985 Effects of corticotropin-releasing factor, neurohypophyseal peptides, and catecholamines on pituitary function. Federation Proceedings 44 189-195.

Roberto M, Cruz MT, Gilpin NW, Sabino V, Schweitzer P, Bajo M, Cottone P, Madamba SG, Stouffer DG, Zorrilla EP et al. 2010 Corticotropin releasing factor-induced amygdala $\gamma$-aminobutyric acid release plays a key role in alcohol dependence. Biological Psychiatry 67 831-839. (doi:10.1016/j. biopsych.2009.11.007)

Roozendaal MM, De Kruijf HF, Reuling RJ, Threels A, Swarts JJ, Wiegant VM \& Mattheij JA 1997 Inhibition of the LH surge by restraint stress in cyclic rats: studies on the role of GABAA and GABAB receptors. Stress 1 241-248. (doi:10.3109/10253899709013744)

Scott CJ \& Clarke IJ 1993a Inhibition of luteinizing hormone secretion in ovariectomized ewes during the breeding season by gamma-aminobutyric acid (GABA) is mediated by GABA-A receptors, but not GABA-B receptors. Endocrinology 132 1789-1796. (doi:10.1210/endo.132.4. 8384997)

Scott CJ \& Clarke IJ 1993b Evidence that changes in the function of the subtypes of the receptors for $\gamma$-amino butyric acid may be involved in the seasonal changes in the negative-feedback effects of estrogen on gonadotropin-releasing hormone secretion and plasma luteinizing hormone levels in the ewe. Endocrinology 133 2904-2912. (doi:10.1210/ endo.133.6.8243318)

Sirivelu MP, Burnett R, Shin AC, Kim C, MohanKumar PS \& MohanKumar SM 2009 Interaction between GABA and norepinephrine in interleukin-1 $\beta$-induced suppression of the luteinizing hormone surge. Brain Research 1248 107-114. (doi:10.1016/j.brainres.2008.10.057)

Terasawa E, Kurian JR, Guerriero KA, Kenealy BP, Hutz ED \& Keen KL 2010 Recent discoveries on the control of gonadotrophin-releasing hormone neurones in nonhuman primates. Journal of Neuroendocrinology 22 630-638. (doi:10.1111/j.1365-2826.2010.02027.x)

Van Cauter E 1988 Estimating false-positive and false-negative errors in analyses of hormonal pulsatility. American Journal of Physiology $\mathbf{2 5 4}$ E786-E794

Wagner EJ, Bosch MA, Kelly MJ \& Ronnekleiv OK 1999 A powerful GABA(B) receptor-mediated inhibition of GABAergic neurons in arcuate nucleus. Neuroreport 10 2681-2687. (doi:10.1097/00001756199908200-00045)

Wintermantel TM, Campbell RE, Porteous R, Bock D, Grone HJ, Todman MG, Korach KS, Greiner E, Perez CA, Schutz G et al. 2006 Definition of estrogen receptor pathway critical for estrogen positive feedback to gonadotropin-releasing hormone neurons and fertility. Neuron $\mathbf{5 2}$ 271-280. (doi:10.1016/j.neuron.2006.07.023)

Received in final form 11 May 2015

Accepted 21 May 2015

Accepted Preprint published online 21 May 2015
(C) 2015 Society for Endocrinology Printed in Great Britain
Published by Bioscientifica Ltd. 